

\section{Earth Sciences and Mathematics}

\section{Volume I}

Edited by

Antonio G. Camacho

Jesús I. Díaz

José Fernández

Birkhäuser

Basel · Boston · Berlin 
Reprint from Pure and Applied Geophysics

(PAGEOPH), Volume 165 (2008) No. 6

\section{Editors:}

Antonio G. Camacho

Jesús I. Díaz

José Fernández

Instituto de Astronomía y Geodesia

Instituto de Matemática Interdisciplinar (IMI)

(CSIC-UCM)

Facultad Ciencias Matemáticas

Universidad Complutense Madrid

Ciudad Universitaria

Plaza de Ciencias 3

Departamento de Matemática Aplicada

Facultad Ciencias Matemáticas

Universidad Complutense Madrid

Ciudad Universitaria

Plaza de Ciencias 3

28040 Madrid

28040 Madrid

Spain

Spain

Email: antonio_camacho@mat.ucm.es

Email: diaz.racefyn@insde.es jose_fernandez@mat.ucm.es

Library of Congress Control Number: 2008932710

Bibliographic information published by Die Deutsche Bibliothek:

Die Deutsche Bibliothek lists this publication in the Deutsche Nationalbibliografie; detailed bibliographic data is available in the Internet at $<\mathrm{http}$ ://nb.ddb.de $>$

\section{ISBN 978-3-7643-8906-2 Birkhäuser Verlag AG, Basel • Boston · Berlin}

This work is subject to copyright. All rights are reserved, whether the whole or part of the material is concerned, specifically the rights of translation, reprinting, re-use of illustrations, recitation, broadcasting, reproduction on microfilms or in other ways, and storage in data banks. For any kind of use permission of the copyright owner must be obtained.

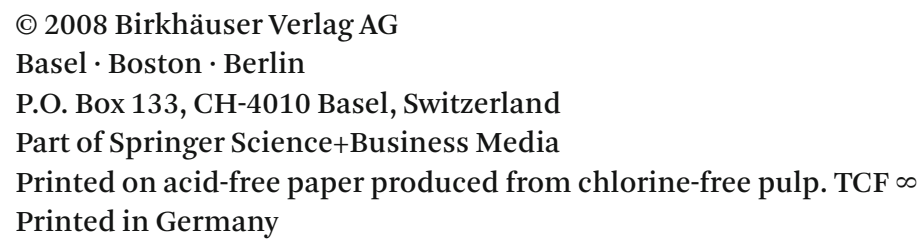


Contents

997 Introduction: Linking Earth Sciences and Mathematics

A. G. Camacho, J. I. Díaz, J. Fernández

1003 A Review of Earthquake Statistics: Fault and Seismicity-Based Models, ETAS and BASS

J. R. Holliday, D. L. Turcotte, J. B. Rundle

1025 A Finite Element Algorithm of a Nonlinear Diffusive Climate Energy Balance Model

R. Bermejo, J. Carpio, J. I. Díaz, P. Galán del Sastre

1049 An Upper Limit to Ground Deformation in the Island of Tenerife, Canary Islands, for the Period 1997-2006

A. Eff-Darwich, O. Grassin, J. Fernández

1071 Multi-Channel Satellite Image Analysis Using a Variational Approach

L. Alvarez, C. A. Castaño, M. García, K. Krissian, L. Mazorra, A. Salgado, J. Sánchez

1095 3D Gravity Inversion by Growing Bodies and Shaping Layers at Mt. Vesuvius (Southern Italy)

G. Berrino, A. G. Camacho

1117 Testing Logselfsimilarity of Soil Particle Size Distribution: Simulation with Minimum Inputs

C. García-Gutiérrez, M. Á. Martín

1131 Steric Sea-Level Change and its Impact on the Gravity Field caused by Global Climate Change

S. Roedelsperger, M. Kuhn, O. Makarynskyy, C. Gerstenecker

1153 A Fractal Interaction Model for Winding Paths through Complex Distributions: Application to Soil Drainage Networks

M. Á. Martín, M. Reyes

1167 The Coherent Pixels Technique (CPT): An Advanced DInSAR Technique for Nonlinear Deformation Monitoring

P. Blanco-Sánchez, J. J. Mallorquí, S. Duque, D. Monells

1195 On the Occurence of Extreme Events in Long-term Correlated and Multifractal Data Sets

M. I. Bogachev, J. F. Eichner, A. Bunde

1209 A Regional Archaeomagnetic Model for the Palaeointensity in Europe for the last 2000 Years and its Implications for Climatic Change F. J. Pavón-Carrasco, M. L. Osete, J. M. Torta, L. R. Gaya-Piqué 